\title{
MENCIPTAKAN SISTEM PELAYANAN PUBLIK YANG BAIK: STRATEGI REFORMASI BIROKRASI DALAM PEMBERANTASAN KORUPSI
}

\author{
(Creating Good Public Service System: \\ Bureaucracy in Reform Strategy Suppression Of Corruption)
}

\author{
Tyas Dian Anggraeni \\ Pusat Penelitian dan Pengembangan Sistem Hukum Nasional \\ Badan Pembinaan Hukum Nasional \\ Jl. Mayjen Sutoyo No. 10 Ciliitan Jakarta \\ Email : tiasdian@yahoo.com
}

Naskah diterima: 15 Oktober 2014; revisi: 17 Nopember 2014; disetujui: 28 Nopember 2014

\begin{abstract}
Abstrak
Pemerintah mempunyai peran yang cukup besar untuk pemenuhan kebutuhan dan kesejahteraan masyarakatnya. Salah satu wujud nyatanya adalah melalui penyelenggaraan pelayanan publik. Rendahnya komitmen pemerintah dalam penyelenggaraan pelayanan publik yang berkualitas dan rentan terhadap tindakan korupsi, menurunkan kepercayaan masyarakat kepada negara. Dikalangan birokrasi sendiri sudah mendarah daging berbagai macam perilaku yang menjadi benih dari tindak pidana korupsi yang besar. Mental korup seakan sudah menjadi penyakit birokrasi dan susah untuk disembuhkan. Tulisan ini membahas potret buruknya pelayanan publik yang dilakukan oleh pemerintah yang mengarah kepada perbuatan tindak pidana korupsi serta membahas bagaimana memperbaiki pelayanan publik yang dilakukan oleh penyelenggara negara melalui kebijakan ditawarkan oleh Presiden terpilih Jokowi dengan menawarkan revolusi mental dalam rangka reformasi birokrasi. Dengan metode sosiolegal dapat disimpulkan bahwa, revolusi mental yang ditawarkan dapat di transformasikan ke dalam program reformasi birokrasi yang seolah-olah tidak pernah berhasil. Dibutuhkan komitmen serta model konkret dari seorang pemimpin guna mensukseskan program reformasi birokrasi. Untuk menjamin adanya keseragaman dalam implementasinya, reformasi birokrasi dapat dituangkan dalam bentuk sistem pembinaan yang dilakukan kepada penyelenggara negara.
\end{abstract}

Kata kunci : pelayanan publik, reformasi birokrasi, korupsi

Abstract
Government has a big role to meet needs and welfare of its own society. As real contribution to the society through public services. Government's lack of commitment to deliver quality public services and vulnerable to corrupt, lower society's trust to the states. Among its bureaucracy ingrained wide range of behaviors that become seeds of huge corruption .Corruption mental seemed become bureaucracy's complication and difficult to heal. This paper discuss the lack of public services performed by government which directing to criminal action also discusss how to improve public services run by state officials through policies offered by elected President Jokowi by offering mental revolution in order to reform the bureacracy. With sosiolegal method can be concluded that offered mental revolution can be transformed into a bureaucratic reform programs as if it never worked. It takes commitment and concrete models of a leader to succeed the bureaucratic reformation program. To ensure uniformity in implementing, bureaucratic reform can realized into character development system to the state officials firmly.

Keywords : public services, bureaucracy reformation, corruption 


\section{A. Pendahuluan}

Berangkat dari pandangan negara kesejahteraan, pemerintah mempunyai peran yang cukup besar tidak lagi hanya membuat dan mempertahankan hukum namun lebih luas lagi yaitu menyelenggarakan kepentingan umum dalam mewujudkan kesejahteraan bagi rakyatnya. ${ }^{1}$ Pemerintah turut aktif dalam pemenuhan dan penyelenggaraan kepentingan umum seperti, kesehatan, pendidikan, perumahan, pemenuhan kebutuhan pangan pembagian tanah dan lain sebagainya. ${ }^{2}$ Dalam dinamika kehidupan bernegara masyarakat semakin sadar akan hak dan kewajibannya. Masyarakat juga semakin paham bahwa pemerintah itu sesungguhnya bukanlah pemilik negara melainkan pelayan masyarakat (public servant). Pemerintah sesungguhnya merupakan penyelenggara negara yang mempunyai tugas ketatalaksanaan (administrative state) yang berorientasi pada negara kesejahteraan (welfare state).

Dalam rangka melaksanakan tugas dan menyelesaikan berbagai macam urusan masyarakat yang menjadi bebannya tersebut, pemerintah menyelenggarakan kegiatan pelayanan publik. Masyarakat pada umumnya sangat bergantung pada pelaksanaan tugas oleh pemerintah tersebut dalam segi sosial dan ekonomi. Di negara seperti Indonesia, di mana kegiatan perekonomian pada umumnya masih diatur dan dikendalikan langsung oleh pemerintah, tingkat ketergantungan masyarakat sangat tinggi. Buruknya pelayanan yang diberikan oleh pemerintah terutama dalam kegiatan perekonomian akan sangat mengganggu lajunya pertumbuhan ekonomi dan menurunkan daya saing nasional.

Presiden terpilih di Indonesia untuk periode 2014-2019, Joko Widodo, menangkap isu tersebut dan menjadikannya sebagai salah satu problem pokok bangsa Indonesia serta merupakan ancaman terhadap wibawa negara. Buruknya pelayanan publik di Indonesia menurunkan tingkat kepercayaan masyarakat kepada institusi publik dan mengakibatkan negara menjadi tidak berwibawa. Hal ini sebagaimana tertuang dalam visi misi Presiden dan Wakil Presiden terpilih Jokowi JK. Dalam visi dan misi sebagaimana yang ditebitkan oleh Komisi Pemilihan Umum (KPU) Jokowi JK menawarkan solusi untuk mengatasi problem pokok bangsa tersebut. Dalam sembilan agenda prioritas yang dikenal dengan Nawa Cita, disebutkan bahwa pemerintahan kedepan akan terus berusaha membangun tata kelola pemerintahan yang bersih, efektif, demokratis, terpercaya dan transparan. Hal ini diwujudkan dengan meningkatkan pengelolaan dan pelayanan informasi di lingkungan pemerintah pusat dan pemerintah daerah. Dilanjutkan dengan secara konsisten menjalankan agenda reformasi birokrasi secara berkelanjutan dengan restrukturisasi kelembagaan, perbaikan kualitas pelayanan publik, meningkatkan kompetensi aparatur, memperkuat monitoring dan supervisi atas kinerja pelayanan publik, serta membuka ruang partisipasi publik melalui citizen charter dalam Undang-Undang Kontrak Layanan Publik. ${ }^{3}$ 
Reformasi birokrasi, merupakan program yang sudah lama dicanangkan, dan masih terus digulirkan serta di gadang-gadang sebagai langkah utama dalam upaya mengembalikan wibawa negara beserta institusinya. Hal tersebut sejalan juga dengan misi Komisi Pemberantasan Korupsi $(K P K)^{4}$ yang akan terus menerus melakukan monitor terhadap penyelenggaraan pemerintahan guna menurunkan praktik korupsi di kalangan birokrasi. Hal tersebut tentunya bukan tanpa alasan, sebagaimana diketahui banyaknya keterlibatan penyelenggara negara, baik itu pejabat maupun pegawai biasa terhadap praktik atau tindakan korupsi. Berdasarkan data yang di rilis oleh KPK sepanjang tahun 2011
- 2014 menunjukan besarnya keterlibatkan penyelenggara negara sebagai aktor atau pelaku kasus tindak pidana korupsi proyekproyek pemerintah. Adapun variasi kasus yang termasuk dalam grand corruption atau menjadi perhatian publik adalah penyuapan dan pengadaan barang dan jasa di lingkungan penyelenggaraan negara, menyusul kemudian kasus yang masuk dalam kategori biasa seperti penyalahgunaan anggaran dan pungutan dalam pelayanan publik, diikuti kasus perizinan dan tindak pidana penyucian uang. ${ }^{5}$ Kondisi tersebut ini semakin memperburuk citra penyelenggara negara, baik itu kepala daerah, pegawai negeri sipil hingga pegawai pada perusahaan milik negara. ${ }^{6}$

Tabel.1 Data Penanganan Korupsi (oleh KPK) Berdasarkan Jenis Perkara Tahun 2004-2014

\begin{tabular}{|c|c|c|c|c|c|c|c|c|c|c|c|c|}
\hline JABATAN & 2004 & 2005 & 2006 & 2007 & 2008 & 2009 & 2010 & 2011 & 2012 & 2013 & 2014 & JUMLAH \\
\hline Pengadaan Barang/Jasa & 2 & 12 & 8 & 14 & 18 & 16 & 16 & 10 & 8 & 9 & 13 & 126 \\
\hline Perijinan & 0 & 0 & 5 & 1 & 3 & 1 & 0 & 0 & 0 & 3 & 4 & 17 \\
\hline Penyuapan & 0 & 7 & 2 & & 13 & 12 & 19 & 25 & 34 & 50 & 11 & 177 \\
\hline Pungutan & 0 & 0 & 7 & & 3 & 0 & 0 & 0 & 0 & 1 & 4 & 17 \\
\hline Penyalahgunaan Anggaran & 0 & 0 & & 3 & 10 & 8 & 5 & 4 & 3 & 0 & 2 & 40 \\
\hline TPPU & 0 & 0 & 0 & 0 & 0 & 0 & 0 & 0 & 2 & 7 & 4 & 13 \\
\hline Merintangi Proses KPK & 0 & 0 & 0 & 0 & 0 & 0 & 0 & 0 & 2 & 0 & 2 & 4 \\
\hline Jumlah & 2 & 19 & 27 & 24 & 47 & 37 & 40 & 39 & 49 & 70 & 40 & 394 \\
\hline
\end{tabular}

Sumber : data di akses dari Anti Corruption Clearing House-ACCH-KPK, http://acch.kpk.go.id/statistik (diakses 4 Oktober 2014)

4 Misi KPK 2011-2015 KPK adalah sebagai berikut: 1) Melakukan koordinasi dengan instansi yang berwenang melakukan pemberantasan TPK.2)Melakukan supervisi terhadap instansi yang berwenang melakukan pemberantasan TPK. 3)Melakukan penyelidikan, penyidikan, dan penuntutan terhadap TPK. 4) Melakukan tindakan-tindakan pencegahan TPK. 5) Melakukan monitor terhadap penyelenggaraan pemerintahan negara. acch.kpk.go.id/ (diakses 1 Oktober 2014).

5 http://acch.kpk.go.id/statistik ( diakses 4 Oktober 2014).

6 Perbuatan korupsi sudah "membalungsumsum" meminjam istilah dalam dalam bahasa Jawa, yang maksudnya sudah merasuk ke dalam segenap sendi sistem penyelenggaraan negara. Korupsi sudah masuk dalam sistem dan seolah sudah menjadi hal yang lumrah terjadi hampir di seluruh instansi publik mulai dari pemerintah pusat maupun daerah. Pejabat publik hadir dengan tanpa ada rasa malu lagi untuk melakukan berbagai penyelewengan yang mengarah ke tindak pidana korupsi, termasuk juga bila yang bersangkutan tertangkap tangan dan menjadi bahan pemberitaan karena tersangkut tindak pidana korupsi. Pihak swasta pun tanpa ragu-ragu turut serta untuk bermain mata, kongkalikong, bila berurusan dengan instansi/pegawai pemerintah. 
Banyak tindakan tercela yang tidak semestinya dilakukan oleh penyelenggara negara atau di kenal dengan "penyakit birokrasi" yang semakin subur. Selayaknya sebuah penyakit yang menular dengan cepat atau di wariskan secara turun temurun, demikian juga dengan fenomena penyakit birokrasi ini. Sehingga bukanlah hal yang aneh ketika banyak pandangan miring terhadap penyelenggara negara, karena hal tersebut di dukung juga oleh banyaknya penyelenggara negara yang terlibat dalam berbagai kasus korupsi. Baik itu penyelenggara negara yang berperan sebagai political state, legal state maupun administrative state. ${ }^{7}$

Secara konkret dapat dikatakan bahwa para penyelenggara negara ini banyak tersangkut dalam kasus korupsi yang berupa penyalahgunaan instrumen kebijakan, prosedur hingga ke bidang penegakan hukum. Tindakan yang dilakukan dapat berupa memberikan janji atau bahkan mengeluarkan ancaman, dimana tindakan tersebut dapat dilakukan seorang penyelenggara negara yang mempunyai kekuasaan dan kepentingan. Praktik tindak pidana korupsi mempunyai segi-segi menguntungkan bagi yang berkuasa, baik itu keuntungan secara langsung berupa penambahan aset atau harta kekayaan seseorang maupun keuntungan berupa sarana untuk menuju kepada suatu tujuan tertentu, baik itu berupa privilege atau keistimewaan tertentu dalam mendapatkan layanan tertentu hingga masuk ke ranah politik.

Sudah banyak buku ataupun tulisan baik di Indonesia maupun di negara-negara lain yang menganalisis sebab-sebab korupsi, modus operandinya serta kekuatan sosial dan politik yang mendukung untuk memeranginya. Bahkan dalam setiap pergantian pemerintahan, program untuk melakukan perbaikan pelayanan publik baik itu melalui tata kelola pemerintahan yang baik hingga program reformasi birokrasi tidak pernah ketinggalan selalu diluncurkan. Namun hal tersebut seolah tidak mampu menghilangkan "penyakit birokrasi" yang berujung pada tindak pidana korupsi. Sebab dan akibat munculnya tindak pidana korupsi seolah seperti benang yang tak bersimpul. Mulai dari rendahnya kesejahteraan hingga rendahnya moral atau integritas penyelenggara negara, ditambah dengan pihak swasta yang turut main mata, di tuduh sebagai alasan. Dalam rangka perbaikan pelayanan publik yang dilakukan oleh penyelenggara negara, Presiden terpilih Joko Widodo, menawarkan sebuah konsep revolusi mental dalam rangka reformasi birokrasi yang diharapkan mampu merubah mental birokrat menjadi pelayan masyarakat yang kompeten.

Berangkat dari pentingnya pelayanan publik yang dilakukan oleh pemerintah, penelitian ini akan membahas bagaimana potret pelayanan publik yang dilakukan oleh pemerintah dan mengarah ke perbuatan tindak pidana korupsi. Selain itu akan dibahas juga bagaimana Presiden Joko Widodo menawarkan konsep revolusi mental yang di transformasikan ke dalam reformasi birokrasi guna memperbaiki pelayanan publik yang dilakukan oleh penyelenggara negara.

\section{B. Metode Penelitian}

Penelitian ini difokuskan pada masalah pelayanan publik yang bukan lagi dilihat sebagai

M. Solly Lubis, Hukum Tata Negara (Bandung : CV Mandar Maju: 1992), hlm. 117-118. 
suatu lembaga otonom di dalam masyarakat namun merupakan sebuah institusi dengan keseluruhan nilai-nilai dan proses-proses yang bekerja di dalam masyarakat tersebut. ${ }^{8}$ Kajian dimulai dengan menganalisa pelaksanaan wewenang publik yang rendahnya terhadap pemenuhan kebutuhan maupun kepuasan publik. Dengan demikian penelitian ini menggunakan pendekatan sosio legal, dengan menggunakan pendekatan ilmu hukum maupun ilmu-ilmu sosial.

Analisa dilakukan dengan mengkaji persoalan hukum dengan tidak menempatkannya sebagai bahan terberi yang terisolasi dari kebudayaan (sistem berpikir, sistem pengetahuan) dan relasi kekuasaan di antara para perumus hukum, penegak hukum, para subjek hukum dan masyarakat secara luas. ${ }^{9}$ Hukum dipandang tidak sekedar sebagai ide normatif, melainkan juga sebagai produk kenyataan kemasyarakatan atau realitas sosial.

Sebagai bahan referensi dipergunakan data sekunder di bidang hukum yang meliputi berbagai macam peraturan perundangundangan yang berkaitan dengan pelayanan publik serta penyelenggaraan negara, hasil karya ilmiah, hasil-hasil penelitian dan literaturliteratur ilmu hukum tentang pelayanan publik dan birokrasi pemerintahan dan di dukung juga dengan berbagai literatur dari ilmu sosial lainnya tentang revolusi mental untuk mendukung analisa di bidang reformasi birokrasi. Dilanjutkan dengan analisa dalam prespektif ilmu hukum, sehingga dapat dicapai hasil yang berorientasi pada penyelesaian masalah hukum. Tidak ada asas-asas hukum yang abstrak, yang berlaku kekal di segala tempat, karena hukum senantiasa berubah, berperan dalam fungsi dasar materil kehidupan bermasyarakat.

\section{Pembahasan}

\section{Potret tindak pidana korupsi dalam pelayanan publik oleh pemerintah}

Pemerintah dalam bingkai negara ketatalaksanaan (administrative state) senantiasa dipertalikan dengan cita-cita negera kesejahteraan (welfare state). ${ }^{10}$ Dalam melaksanakan tugasnya, pemerintah di berikan wewenang yang luas dalam mengatur hingga menyelesaikan segala permasalahan yang dialami oleh warga masyarakatnya. ${ }^{11}$ Pengaturan yang dilakukan oleh pemerintah, terutama di Indonesia dilakukan hampir di sebagian besar bidang kehidupan. Pemerintah mengatur masalah pertahanan keamanan hingga ketersediaan sandang, pangan, kesehatan bahkan pemerintah mengatur juga sisi religi atau masuk ke dalam ranah pribadi, dengan pengaturan agama di Indonesia yang tercantum dalam Kartu Tanda Penduduk (KTP).

A.M. Donner dalam Djenal Hoesen, membagi pemerintahan dalam dua

8 Satjipto Raharjo, Sosiologi Hukum "Perkembangan Metode dan Pilihan Masalah, (Surakarta: Cet. Pertama: UMS Press : 2002) hlm. 5.

$9 \quad$ Sulistyowati Irianto, "Meretas Jalan Keadilan Bagi kaum Terpinggirkan dan Perempuan (Suatu Tinjauan SocioLegal)”, Pidato Pengukuhan Guru Besar Tetap dalam Ilmu Antropologi Hukum pada Fakultas Hukum Universitas Indonesia, 22 April 2009, hlm. 33.

10. M. Solly Lubis, Asas-asas Hukum Tata Negara (Bandung : Alumni : 1982) hlm. 31.

11 Menurut Maurice Duverger dan Hans Kelsen, tugas pemerintah sekarang tidak hanya melaksanakan undangundang atau untuk merealisasikan yang disebut Jellinek sebagai kehendak negara (staatswill; general will). Akan tetapi lebih luas dari itu adalah menyelenggarakan kepentingan umum (public service) 
tingkat kekuasaan (dwipraja), yaitu alat pemerintahan yang berfungsi menentukan haluan politik negara (politiek taakstelling) dan alat pemerintahan yang berfungsi menyelenggarakan / merealisasikan politik negara yang telah di tentukan ( verwekenlijking van de taak). ${ }^{12}$ Termasuk di dalam alat pemerintah yang berfungsi menyelenggarakan politik negara yang telah di tentukan adalah mengelompokkan pemerintah sebagai organ atau badan atau alat perlengkapan negara atau badan pelaksana. Pemerintah dalam arti sempit hanya sebagai badan pelaksanaan (eksekutief, bestuur, bestuurzorg) dapat di lihat sebagai susunan administrasi negara yang terdiri dari kementerian, direktorat, biro hingga unit-unit terkecil di wilayah termasuk juga penyelenggara pemerintahan daerah.

Sesuai dengan pembagian tugas pemerintah tersebut, tugas pelayanan publik menjadi tanggung jawab pemerintah sepenuhnya. Hingga saat ini belum ada pembagian terhadap tugas pelayanan publik yang di bagikan kepada pihak swasta atau di luar susunan pemerintahan. Monopoli pemerintah terhadap penyelenggaraan pelayanan publik bukan tidak mungkin menjadi salah satu faktor rendahnya kinerja yang berdampak kepada rendahnya hasil yang menjadi keluarannya.

Berdasarkan Undang-Undang Nomor 25 Tahun 2009 tentang Pelayanan Publik ${ }^{13}$, dalam Pasal 1 , disebutkan bahwa:

(1) Pelayanan publik adalah kegiatan atau rangkaian kegiatan dalam rangka pemenuhan kebutuhan pelayanan sesuai dengan peraturan perundang-undangan bagi setiap warga negara dan penduduk atas barang, jasa, dan/ atau pelayanan administratif yang disediakan oleh penyelenggara pelayanan publik.

(2) Sedangkan penyelenggara pelayanan publik yang selanjutnya disebut Penyelenggara adalah setiap institusi penyelenggara negara, korporasi, lembaga independen yang dibentuk berdasarkan undang-undang untuk kegiatan pelayanan publik, dan badan hukum lain yang dibentuk berdasarkan undang-undang untuk kegiatan pelayanan publik, dan badan hukum lain yang dibentuk semata-mata untuk kegiatan publik.

Adapun ruang lingkup pelayanan publik, sebagaimana diatur dalam Pasal 5,

(1) Ruang lingkup pelayanan publik meliputi pelayanan barang publik dan jasa publik serta pelayanan administratif yang diatur dalam peraturan perundang-undangan.

(2) Ruang lingkup sebagaimana dimaksudkan pada ayat (1) meliputi pendidikan, pengajaran, pekerjaan dan usaha, tempat tinggal, komunikasi dan informasi, lingkungan hidup, kesehatan, jaminan sosial, energi, perbankan, perhubungan, sumber daya alam, pariwisata, dan sektor strategis lainnya.

(3) Pelayanan publik sebagaimana dimaksud pada ayat (1) meliputi :

a. pengadaan dan penyaluran barang publik yang dilakukan oleh instansi pemerintah yang sebagian atau seluruh dananya bersumber dari anggaran pendapatan 
dan belanja negara dan/ atau anggaran pendapatan dan belanja daerah;

b. pengadaan dan penyaluran barang publik yang dilakukan oleh suatu badan usaha yang modal pendiriannya sebagian atau seluruhnya bersumber dari kekayaan negara dan /atau kekayaan daerah yang dipisahkan; dan

c. pengadaan dan penyaluran barang publik yang pembiayaannya tidak bersumber dari anggaran pendapatan dan belanja negara atau anggaran pendapatan dan belanja daerah atau badan usaha yang modal pendiriannya sebagian atau seluruhnya bersumber dari kekayaan negara dan/atau kekayaan daerah yang dipisahkan, tetapi ketersediaannya menjadi misi negara yang ditetapkan dalam peraturan perundang-undangan.

(4) Pelayanan atas jasa publik sebagaimana dimaksud pada ayat (1) meliputi :

a. penyediaan jasa publik oleh instansi pemerintah yang sebagian atau seluruh dananya bersumber dari anggaran pendapatan dan belanja negara dan/ atau anggaran pendapatan dan belanja daerah;

b. penyediaan jasa publik oleh suatu badan usaha yang modal pendiriannya sebagian atau seluruhnya bersumber dari kekayaan negara dan/atau kekayaan negara daerah yang dipisahkan;dan

c. penyediaan jasa publik yang pembiayaannya tidak bersumber dari anggaran pendapatan dan belanja negara atau anggaran pendapatan dan belanja daerah atu badan usaha yang modal pendiriannya sebagian atau seluruhnya bersumber dari kekayaan negara dan/ atau kekayaan daerah yang dipisahkan, tetapi ketersediaannya menjadi misi negara yang ditetapkan dalam peraturan perundang-undangan.

Berdasarkan apa yang telah diatur dalam Undang-Undang Pelayanan Publik lebih mengarah kepada pelayanan umum dan langsung melayani atau berhadapan langsung dengan masyarakat. Namun lamanya waktu yang di butuhkan untuk oleh masyarakat dalam pelayanan publik serta di dukung oleh birokrasi yang berbelit-belit dan nampak diada-adakan seperti untuk memberikan masukan non APBN mengakibatkan masyarakat apatis terhadap pelayanan publik, terutama yang mempunyai tugas dan fungsi menyelenggarakan pelayanan umum.

Padahal apabila menilik definisi pemerintah sebagai penyelenggara negara yang diatur dalam Pasal 1 angka 2 Undang-Undang Nomor 28 Tahun $1999^{14}$ tentang Penyelenggara Negara yang Bersih dan Bebas dari Korupsi Kolusi dan Nepotisme :

"Penyelenggara negara yang menjalankan fungsi eksekutif, legislatif, yudikatif yang menaati asas-asas umum penyelenggaraan negara dan bebas dari praktek Korupsi, Kolusi dan Nepotisme, serta perbuatan tercela lainnya"

Jelas memberikan rambu bahwa setiap penyelenggara negara harus profesional dan mentaati asas-asas umum penyelenggaraan negara yang baik. Aturan tersebut tentunya secara normatif sudah mengatur setiap langkah yang menghasilkan pelayanan yang prima kepada masyarakat. Namun, kembali

14 Undang-Undang Nomor 28 Tahun 1999 (LN no 75 TLN no 3854 tahun 2009). 
lagi penyakit birokrasi yang menular dengan sangat cepat seolah merusak integritas setiap penyelenggara negara. Bahkan penyelenggara yang mempunyai masa kerja masih rendah, atau baru saja masuk ke dunia birokrasi pun tidak imun dari virus penyakit birokrasi tersebut.

Dalam Undang-Undang Nomor 31 Tahun 1999 jo Undang-Undang Nomor 20 Tahun 2001 tentang Pemberantasan Tindak Pidana Korupsi ${ }^{15}$, telah di jelaskan secara detil dengan berbagai model yang menyebutkan bahwa pengertian korupsi mencakup perbuatan:

a. Melawan hukum, memperkaya diri orang/ badan lain yang merugikan keuangan / perekonomian negara (diatur dalam Pasal 2).

b. Menyalahgunakan kewenangan karena jabatan/kedudukan yang dapat merugikan keuangan/kedudukan yang dapat merugikan keuangan/perekonomian negara (diatur dalam Pasal 3)

c. Kelompok delik penyuapan (diatur dalam Pasal 5,6, dan 11)

d. Kelompok delik penggelapan dalam jabatan (diatur dalam Pasal 8, 9, dan 10)

e. Delik pemerasan dalam jabatan (diatur dalam Pasal 12)

f. Delik yang berkaitan dengan pemborongan (diatur dalam Pasal 7)

g. Delik gratifikasi (diatur dalam Pasal 12B dan 12C)

Berdasarkan rumusan tersebut dapat disimpulkan bahwa korupsi ialah perbuatan yang buruk seperti penggelapan uang, penerimaan uang sogok dan sebagainya termasuk perbuatan menggunakan barang publik, bisa berupa uang dan jasa, untuk kepentingan memperkaya diri dan bukan untuk kepentingan publik. Dalam pelayanan publik, tindak pidana korupsi yang besar dapat dimulai dari adanya tindakan maladministrasi atau dapat di katakan bahwa maladministrasi ujung pangkal tindak pidana korupsi pada ranah pelayanan publik. Pada umumnya, masyarakat memahami maladministrasi sebagai kesalahan administratif yang tidak terlalu penting (trivial matters). Padahal menurut pasal 1 angka 3 Undang-Undang Nomor 37 Tahun 2008 tentang Ombudsman Republik Indonesia ${ }^{16}$, pengertian maladministrasi tersebut sangat luas dan mencakup banyak hal yang dapat menimbulkan kerugian materiil maupun immateriil serta situasi ketidakadilan yang merugikan hak-hak warga negara.

Ada 9 (sembilan) kriteria yang menjadi kategori maladministrasi sebagaimana terdapat dalam buku saku Ombudsman, (1) Perilaku dan perbuatan melawan hukum (2) Perilaku dan perbuatan melampaui wewenang, (3) Menggunakan wewenang untuk tujuan lain dari yang menjadi tujuan wewenang tersebut, (4) Kelalaian (5) Pengabaian kewajiban hukum (6) Dalam penyelenggaraan pelayanan publik (7) Dilakukan oleh Penyelenggara Negara dan pemerintahan (8) Menimbulkan kerugian materiil dan/atau immaterial (9) Bagi masyarakat dan orang perseorangan. ${ }^{17}$ Katakata maladministrasi dengan definisinya untuk pertama kalinya secara khusus tercantum di dalam Pasal 1 angka 3 Undang-Undang 
No. 37 Tahun 2008 tentang Ombudsman Republik Indonesia. Dalam Pasal 1 angka 3 ini, maladministrasi bukan hanya berbentuk perilaku/tindakan tetapi juga meliputi Keputusan dan Peristiwa yang melawan hukum, melampaui wewenang, menggunakan wewenang untuk tujuan lain dari yang menjadi tujuan wewenang tersebut, termasuk kelalaian atau pengabaian kewajiban hukum dalam penyelenggaraan pelayanan publik yang dilakukan oleh Penyelenggara Negara dan pemerintahan, termasuk perseorangan yang membantu pemerintah memberikan pelayanan publik yang menimbulkan kerugian materiil dan/atau immateriil bagi masyarakat dan orang perseorangan. ${ }^{18}$

Landasan hukum yang langsung menyebut tentang pencegahan dan penyelesaian maladministrasi diatur juga dalam UndangUndang Republik Indonesia Nomor 37 Tahun 2008 tentang Ombudsman Republik Indonesia Pasal 4 huruf $d$, disebutkan bahwa:

Ombudsman bertugas:

a. menerima Laporan atas dugaan maladministrasi dalam penyelenggaraan pelayanan publik;

b. melakukan investigasi atas prakarsa sendiri terhadap dugaan maladministrasi dalam penyelenggaraan pelayanan publik;
c. melakukan upaya pencegahan maladministrasi dalam penyelenggaraan pelayanan publik

Secara etimologis Philipus M. Hadjon berpendapat bahwa mal-administratif berasal dari bahasa latin, mal berarti jelek, jahat, dan administrare artinya melayani. Dengan demikian mal-administratif mengandung arti pelayanan yang jelek atau buruk. ${ }^{19}$ Berdasarkan Laporan tahunan dari Komisi Ombudsman Eropa mendefinisikan bahwa: maladministration occurs when a public body fail to act in accordance with the rule or principle which is binding upon it. Definisi tersebut sangat dekat dengan pengertian korupsi yang merupakan ajakan (dari seorang pejabat politik) dengan pertimbangan-pertimbangan yang tidak semestinya (misalnya suap) untuk melakukan pelanggaran tugas. ${ }^{20}$ Dengan demikian semakin tegas bahwa tindakan maladministrasi sangat dekat dengan tindak pidana korupsi.

Dalam kegiatan pelayanan publik apabila melihat dari proses terjadinya perilaku korupsi dapat dibedakan sebagai berikut:

a. korupsi yang bersifat eksternal yaitu dengan adanya keterlibatan pihak ketiga. Biasanya terjadi karena seseorang mempunyai kewenangan yang strategis dalam menentukan jalannya pelayanan

\footnotetext{
18 Undang-Undang Nomor 37 tahun 2008 tentang Ombudsman Republik Indonesia (LN no 139 TLN no 4899 Tahun 2008).

19 Philipus M. Hadjon, Pengantar Hukum Administrasi Indonesia, (Yogyakarta: Gadjah Mada University Press: tahun 2001) hlm. 10-20.

20 Selanjutnya disebutkan bahwa corruptio itu berasal pula dari kata asal corrumpere, suatu kata Latin yang lebih tua. Dari bahasa Latin itulah turun ke banyak bahasa Eropa seperti Inggris, yaitu Corruption, corrupt; Perancis, yaitu corruption; dan Belanda, yaitu corruptie (korruptie). Kita dapat memberanikan diri bahwa dari bahasa Belanda inilah kata itu turun ke Bahasa Indonesia, yaitu "korupsi". Arti harfiah dari kata itu ialah kebusukan, keburukan, kebejatan, ketidakjujuran, dapat disuap, tidak bermoral, penyimpangan dari kesucian, kata-kata atau ucapan yang menghina atau memfitnah http://elibrary.ub.ac.id/handle/123456789/27565?mode=full (diakses 23 September 2014)
} 
publik, baik dalam mengeluarkan ijin atau surat atau rekomendasi tertentu. Dengan kewenangan yang di milikinya tersebut, seseorang mensyaratkan adanya imbalan tertentu baik berupa materi maupun jasa untuk mempercepat kelancaran pelayanan publik.

b. Penyogokan atau penyuapan, tindakan ini juga melibatkan orang lain. Tindakan semacam ini seringkali terjadi pada kantor atau instansi yang mempunyai tugas dan fungsi melakukan pelayanan, menerbitkan surat ijin, rekomendasi dan sebagainya sehingga mereka yang berkepentingan lebih suka mencari calo, memberi uang pelicin agar urusannya dapat diperlancar. Pemberian suap atau sogokan baik itu berupa materi atau jasa tersebut dilakukan untuk mempengaruhi objektivitas dalam membuat keputusan. Keputusan yang dibuat akan menguntungkan si pemberi suap.

Sebagai contoh adalah hasil temuan KPK dalam kasus tindak pidana korupsi penyelenggaraan ibadah haji. Banyak sekali temuan-temuan maladministrasi terkait dengan pelayanan penyelenggaraan ibadah haji oleh Kementerian Agama yang dapat dipastikan mengarah pada tindak pidana korupsi. Beberapa catatan yang ditemukan:

a. Sistem indirect cost atau biaya operasional penyelenggaraan haji ini dinilai cukup memberatkan para jamaah dan tidak transparan dalam pengelolaannya. Pada 2011, total indirect cost yang digunakan untuk kepentingan petugas haji (baik di pusat, daerah dan Arab Saudi) sebesar Rp 137,3 miliar. Hal ini berarti bahwa setiap jamaah haji Indonesia yang jumlahnya hampir 200 orang harus mensubsidi sekitar
Rp 653.834,96 untuk kepentingan petugas haji.

b. Untuk pengelolaan uang atau biaya penyelenggaraan haji, misalnya, seseorang menyetorkan sejumlah dana untuk mengikuti ibadah haji di tahun ini, namun ternyata dia masuk ke dalam daftar tunggu dan baru bisa diberangkatkan ibadah haji beberapa tahun kemudian. Uang yang telah disetorkan tersebut apabila disimpan dalam jangka waktu beberapa tahun tentunya sudah menghasilkan bunga. Bunga yang dihasilkan dari dana jamaah itu justru digunakan untuk operasional haji tahun ini dimana si jamaah tak ikut di dalamnya.

c. Temuan selanjutnya tidak jelasnya format laporan sisa biaya operasional penyelenggaraan ibadah haji yang disetorkan ke Dana Abadi Umat (DAU).

d. Selain temuan yang bersifat materi berupa tidak transparan dan buruknya sistem pelaporan keuangan. Aspek kelembagaan pun menjadi temuan, terkait ketidaksesuaian antara tugas pokok dan fungsi masing-masing unit di lingkungan Ditjen Penyelenggaraan Haji dan Umroh.

e. Temuan yang terkait dengan tata laksana, tidak ditemukan adanya standar operasional prosedur dan standar pelayanan minimum dalam pelayanan haji.

f. Hal ini belum termasuk aspek inefisiensi manajeman sumber daya manusia.

Pemerintah tidak tinggal diam dengan tinggi nya tindak pidana korupsi yang dilakukan oleh penyelenggara negara. Sudah banyak aturan yang dikeluarkan untuk memerangi dan memberantas tindak pidana korupsi, seperti :

a. Delik yang dapat merugikan keuangan negara atau perekonomian negara (Pasal 
2 dan Pasal 3 Undang-Undang Nomor 31 Tahun 1999 tentang Pemberantasan Tindak Pidana Korupsi).

b. Delik penyuapan memberikan atau menjanjikan sesuatu Pasal 5 UndangUndang Nomor 31 Tahun 1999 Jo UndangUndang Nomor 20 Tahun 2001 yang diadopsi dari Pasal 209 KUHP.

c. Delik penyuapan memberikan atau menjanjikan sesuatu kepada Hakim dan Advokat Pasal 6 Undang-Undang Nomor 31 Tahun 1999 Jo Undang-Undang Nomor 20 Tahun 2001 yang diadopsi dari Pasal 210 KUHP.

d. Delik dalam hal membuat bangunan dan menjual bahan bangunan dan korupsi dalam menyerahkan alat keperluan TNI dan Kepolisian RI Pasal 7 Undang-Undang Nomor 31 Tahun 1999 Jo Undang-Undang Nomor 20 Tahun 2001 yang diadopsi dari Pasal 387 dan 388 KUHP.

e. Delik Pegawai Negeri menggelapkan Uang dan Surat Berharga Pasal 8 Undang-Undang Nomor 31 Tahun 1999 Jo Undang-Undang Nomor 20 Tahun 2001 yang diadopsi dari Pasal 415 KUHP.

f. Delik Pegawai Negeri memalsu bukubuku dan daftar-daftar yang khusus untuk pemeriksaan administrasi Pasal 9 UndangUndang Nomor 31 Tahun 1999 Jo UndangUndang Nomor 20 Tahun 2001 yang diadopsi dari Pasal 416 KUHP

g. Delik yang berhubungan dengan hukum acara Pemberantasan Korupsi : mencegah, merintangi/menggagalkan penyidikan, penuntutan, dan pemeriksaan TPK (Pasal 21 Undang-Undang Nomor 31 Tahun 1999).

\section{Reformasi Birokrasi dalam Pelayanan Publik guna Menghambat Praktik Tindak Pidana Korupsi dan meningkatkan daya saing nasional}

Birokrasi adalah alat kekuasaan bagi yang menguasainya, di mana para pejabatnya secara bersama-sama berkepentingan dalam kontinuitasnya. Birokrasi merupakan suatu kiasan; penguasaan oleh "biro", analog dengan aristrokrasi; otokrasi; demokrasi; teknokrasi. Mengacu pada struktur bukan pada fungsinya, tetapi terdapat banyak perbedaan mengenai definisi struktur yang di capai oleh Birokrasi; dua dimensi perbedaan variasi, dapat di definisikan melalui contex dan conten. ${ }^{21}$

Untuk mendorong terbentuknya suatu pemerintahan yang bersih dan berwibawa maka segenap aparatur pemerintah wajib melaksanakan asas-asas umum pemerintahan yang baik (good governance). ${ }^{22}$ apabila diamati apa yang dikerjakan oleh birokrat dapat di kategorikan sebagai pelaksanaan atas hak, kewajiban dan tanggung jawabnya serta peranannya dalam pelaksanaan pelayanan publik dalam arti yang luas. Pemerintah beserta seluruh aparatnya masuk dalam proses pembangunan nasional yang tidak hanya bertanggungjawab dalam penyusunan kebijakan, strategi, rencana, program dan proyek namun dapat berperan dalam seluruh

21 Benyamin Hoessein,"Birokrasi dan Pembangunan," makalah disampaikan pada Penyegaran Staf Pengajar bagian Hukum Administrasi Negara Fakultas Hukum Universitas Indonesia, Depok, 1982. hlm. 1.

22 Ginrindro Pringgodigdo,"Hukum dan pembangunan,” makalah disampaikan pada Program pendidikan Non Degree / bersertifikat bagi Pemuka Masyarakat sebagai realisasi kerjasama Pusat Pengabdian Masyarakat Universitas Indonesia dan Pemerintah Daerah Tingkat II Kabupaten Sukabumi, 28 Oktober 1982, hlm. 14-18. 
segi proses penyelenggaraan negara dengan berperan sebagai :

a. Modernisator, seorang birokrat diharapkan memiliki pola pemikiran yang maju dan tidak selalu berpatokan kepada pandangan lama.

b. Katalisator, seorang birokrat harus mampu sebagai penghubung atau jembatan pemerintah dengan masyarakat. Birokrat di tuntut untuk mampu menyatukan persepsi masyarakat akan pentingnya pembangunan, mampu memanfaatkan sumber daya alam dengan baik untuk kesejahteraan masyarakat dan memberikan perlindungan hukum

c. Dinamisator, seorang birokrat di harapkan mampu berperan sebagai pemandu agar tercipta kondisi yang dinamis dalam masyarakat

d. Stabilisator, harus mampu menciptakan stabilitas dalam masyarakat

e. Motivator, harus mampu menjadi teladan di dalam masyarakat.

Beratnya beban serta tanggung jawab yang harus di pikul oleh seorang birokrat merupakan tantangan bagi pemimpin negara (dalam hal ini Presiden) untuk mampu mengarahkan segenap aparaturnya agar mampu menjadi birokrat yang ideal.

Buruknya citra birokrasi bukan baru-baru ini saja mengemuka. Seolah seperti warisan perilaku jelek yang melekat dalam birokrat dari masa ke masa.Kalau kita menengok kebelakang, dalam dasawarsa 1950 an ada seorang dosen universitas di Yogyakarta pada sebuah seminar mengatakan, bahwa korupsi di Indoneisa sudah membudaya. Melihat perkembangan korupsi dikalangan pemerintahan dan sedikitnya usaha untuk memberantasnya maka ucapan dosen itu menyebar dan dibenarkan oleh banyak pimpinan serta pejabat yang mengecam korupsi, akan tetapi tidak mempunyai kekuatan untuk memberantasnya. Saat ini korupsi dikalangan pemerintah merajalela di berbagai kalangan bergandengan tangan dengan kolusi yang melibatkan pejabat pemerintah dan pengusaha kaya untuk mendapatkan keuntungan bersama. Hal ini ditambah lagi dengan gejala suap atau pungli yang disetorkan kepada pejabat pemerintah yang memegang kekuasaan vital dalam urusan business atau hukum bagi orang yang berkepentingan. ${ }^{23}$

Pernyataan tersebut seolah mendukung anggapan korupsi sistemik, yaitu korupsi yang dilakukan oleh sebagian besar (kebanyakan) orang dalam suatu organisasi (melibatkan banyak orang). Dikatakan sistemik karena tindakan korupsi ini bisa diterima secara wajar atau biasa (tidak menyimpang) oleh orang-orang yang berada di sekitarnya yang merupakan bagian dari suatu realita. Jika ketahuan maka diantara mereka akan saling melindungi, menutup-nutupi dan mendukung satu sama lain demi untuk menyelamatkan orang yang ketahuan tersebut.

Guna menangani penyakit, akan lebih efektif ketika mengetahuai penyakitnya. Begitupun penyakit birokrasi, penanganan patologi birokrasi dan terapinya dimaksudkan untuk mengidentifikasi penyakit birokrasi dan mencarikan terapi yang paling efektif. Patologi birokrasi dapat di kategorikan dalam lima kelompok sebagai berikut ${ }^{24}$ :

Rober Klitgaard, Membasmi Korupsi, penerjemah Hermojo, (Jakarta: Yayasan Obor Indonesia: edisi ke 3: cetakan ke 3: 2005) hlm. 67.

24 Siagian, Sondang P, Patologi birokrasi: analisis, identifikasi dan terapinya (Indonesia: Ghalia: 1994) hlm. 35 - 81. 
a. Patologi yang timbul karena persepsi dan gaya manajerial para pejabat di lingkungan birokrasi, misalnya penyalahgunaan wewenang dan jabatan, penguburan dan pengaburan masalah sehingga penyelesaiannya dapat direkayasa yang menguntungkan pejabat atau birokrat yang bersangkutan, menerima suap.

b. Patologi yang disebabkan karena kurangnya atau rendahnya pengetahuan dan ketrampilan para petugas pelaksana berbagai kegiatan operasional

c. Patologi yang timbul karena tindakan para anggota birokrasi yang melanggar normanorma hukum dan peraturan perundangundangan yang berlaku.

d. Patologi yang dimanifestasikan dalam perilaku para birokrat yang disfungsional atau negatif

e. Patologi yang merupakan akibat situasi internal dalam berbagai instansi dalam lingkungan pemerintahan.

Terdapat beberapa model untukmemberikan terapi guna mengatasi permasalahan tersebut, Peter Langseth mengungkapkan bahwa setidaktidaknya ada beberapa strategi yang dapat diterapkan untuk mengurangi intensitas korupsi di yaitu:

a. Memutus serta merampingkan (streamlining) jaringan proses birokrasi yang bernuansa primordial di kalangan penentu yang, baik itu yang berada di lembaga eksekutif, legislatif maupun yudikatif, sehingga tata kerja dan penempatan pejabat pada jabatan atau posisi-posisi tertentu benar-benar dapat dilaksanakan secara akuntabel dan profesional serta dilaksanakan dengan pertimbangan profesionalisme dan integritas moral yang tinggi;

b. Menerapkan sanksi pidana yang maksimal secara tegas, adil dan konsekuen tanpa ada diskriminasi bagi para pelaku korupsi, dalam arti bahwa prinsip-prinsip negara hukum benar-benar harus diterapkan secara tegas dan konsekuen, terutama prinsip equality before the law;

c. Para penentu kebijakan di bidang pemerintahan maupun di bidang penegakan hukum harus memiliki kesamaan visi, profesionalisme, komitmen, tanggung jawab dan integritas moral yang tinggi dalam menyelesaikan kasus-kasus korupsi; ${ }^{25}$ dan

d. Membuat pelayanan administrasi perizinan/ administrasi pembuatan dokumen (KTP, Akte Kelahiran, dll) dengan sistem satu atap atau One Stop Service.

e. Membuat standarisasi pelayanan (Standart Operating Procedure/SOP) dan sertifikasi pelayanan, seperti melalui International Organization For Standardization (ISO)

f. Penandatanganan Pakta Integritas dari para pejabat

g. Membuat layanan Pengaduan Publik baik secara elektronik (website, sms dan media sosial : Facebook,Twitter,BBM) ataupun konvensional ( Inspektorat)

Langkah nyata yang harus segera diimplementasikan secara konkret adalah memberikan pembinaan atau lebih ekstrimnya memperbaiki mental birokrat atau reformasi birokrasi. Pada saat diselenggarakan kampanye pemilihan presiden dan wakil Presiden periode

25 Peter Langseth et. Al, The Role of a National Integraty System in Fighting Corruption, The Economoc Developmen Institute of the World bank, 1997. 
2014-2019, calon Presiden (pada saat itu) menawarkan adanya revolusi mental di segala sisi atau sendi kehidupan yang secara sederhana termasuk juga memasukkan revolusi mental ke dalam konsep reformasi birokrasi. Konsep revolusi mental model Joko Widodo dapat dibagi dalam 3 (tiga) tahapan yaitu pembangunan sistem, manajemen pembangunan infrastruktur dan manajemen kepuasan masyarakat. Revolusi Mental di dalam ilmu manajemen sebetulnya bukan hal baru. Istilah ini menjadi istilah penting manajemen ilmiah yang dikembangkan oleh Profesor Frederick W. Taylor. ${ }^{26}$

Istilah revolusi mental ini juga pernah disampaikannya di depan Konggres Khusus, Amerika Serikat pada tahun 1912 yang membuat situasi heboh karena mengingat sistem manajemen birokrasi dan juga industri pada waktu itu masih mengandalkan pada model pembagian kerja dan juga supervisi yang ketat yang dianggap masih ortodok. Taylor mengatakan empat hal utama untuk mencapai revolusi mental yang intinya ditekankan pada empat hal. Pertama, bangun metode ilmiah untuk tugas baru. Kedua, untuk melaksanakan tugas, perlu seleksi ilmiah, pelatihan dan pengembangan orang agar kompeten. Ketiga, setelah pekerjaan jelas tujuannya, orang terbaik dipilih untuk menjamin pekerjaan dapat berjalan dengan baik. Keempat, fungsi yang prinsip adalah pentingnya perencanaan yang musti terpisah dengan pelaksanaan.

Revolusi mental menekankan pada orang dan sistem yang ingin diciptakan oleh Joko Widodo bagaimana sebuah manajemen itu bisa berjalan secara simple, tidak banyak birokrasi, dan tidak menghasilkan biaya yang lebih banyak. Tidak kalah penting dari itu, bahwa perubahan apapun itu, tentu dibutuhkan mental revolusioner mengingat tantangan bangsa ini sangat kompleks. Siapapun Presiden yang terpilih nanti, kualitas pemimpin mendatang harus mampu menempatkan diri sebagai seorang pemimpin eksekutif yang memiliki motif pelayanan yang kuat. Sebab manajemen revolusi mental itu harus datang dari pucukpucuk pimpinan bangsa ini. Di era digital saat ini, kita memang butuh pembaharuan manajemen dalam banyak hal untuk mengatasi tuntutan masyarakat yang serba ingin cepat terlayani. Kita butuh banyak ide-ide manajemen revolusioner untuk keluar dari pola manajemen pemerintahan lama yang serta birokratif dan lamban.

Tindakan nyata dari revolusi mental birokrasi terhadap reformasi birokrasi lebih mudah dengan pendekatan sistem. Sistemnya harus dibangun untuk memberikan pelayan terbaik pada masyarakat dengan membasmi budaya korup dan malas. Menutup semua celah dan pintu-pintu budaya korup dan malas. Sistem yang dibangun tersebut harus bisa berjalan dengan konsisten dan bagi yang tidak bisa mengikuti sistem harus ditinggal atau dipecat. Tentu saja agar sistem tersebut benar-benar berjalan harus ada kontrol yang ketat dan berkesinambungan. Presiden Joko Widodo yang pada waktu itu masih menjadi Gubernur DKI, memberikan contoh dengan melakukan pengawasan langsung di lapangan melalui blusukan. Melalui blusukan, Joko Widodo tahu persis kelebihan dan kekurangan dari sistem

26 http://politik.kompasiana.com/2014/07/07/revolusi-mental-bukan-marxisme-komunisme (diakses 3 Oktober 2014). 
yang dibangunnya. Sebagai pemimpin yang berjiwa melayani, Joko Widodo mengakui tugas terberatnya dalam memberikan pelayanan terbaik untuk masyarakat adalah mengubah mental dan perilaku birokrasi dan masyarakat itu sendiri. Namun demikian, menurut Joko Widodo sulit bukan berarti tidak bisa dilakukan. ${ }^{27}$

Percepatan pelaksanaan reformasi birokrasi oleh Joko Widodo dimulai dengan revolusi mental yang dimulai dengan mengubah mental dan sikap. Untuk kalangan birokrat tentunya bukan hanya tentang kenaikan gaji dan menambah fasilitas namun untuk merubah pola pikir (mind set) dan budaya kerja (culture set) di jajaran birokrasi untuk merubah kesan birokrat di mata masyarakat telah di wujud nyatakan atau di contohkan secara langsung oleh seperti misalnya :

a. Adanya lelang jabatan di kalangan birokrat, mungkin dalam dunia administrasi kepegawaian dapt menjawab asas right men in the right place. Dalam kaitannya dengan pelayanan publik dapat di utamakan terlebih dahulu lelang jabatan bagi birokrat yang membidangi langsung pelayanan publik. Pada awal periode pemerintahan Joko Widodo menjadi Gubernur DKI Jakarta, metode ini menjadi sangat terkenal, bukan hanya jabatan setingkat dinas dan badan, namun sampai ke level lurah dan camat juga dilelang. Metoda pengisian jabatan publik ini merupakan langkah awal yang diharapkan dapat menciptakan tata laksana pemerintahan yang baik dan sesuai dengan aspirasi masyarakat. Penataan sumber daya manusia ini juga harus diikuti dengan perbaikan sistem remunerasi

b. Menggunakan fasilitas pejabat yang sudah ada Presiden terpilih Joko Widodo menolak rencana pemerintahan Presiden Susilo Bambang Yudhoyono untuk membelikan mobil mewah baru bagi menteri pemerintahan Joko Widodo mendatang. Keputusan ini dinilai sebagai komitmen untuk kedepankan pelayanan publik daripada meningkatkan fasilitas pejabat.

c. Revolusi mental ini berupa penyadaran terhadap para birokrat yang selama ini selalu menunggu perintah dari atasannya. Padahal pemerintahan yang baik adalah yang pelayan publiknya bisa inovatif mencari berbagai pekerjaan

d. Program fenomenal lainnya adalah masalah perijinan. Sebelumnya dikalangan birokrat terkenal dengan, "Jika bisa dipersulit kenapa harus dipermudah!". Fakta dilapangan menunjukan pemeo tersebut benar-benar nyata. Jika berurusan dengan birokrasi selalu rumit dan berbelit-belit, menghabiskan waktu, tenaga, uang dan menyebalkan. Kondisi yang menggambarkan budaya korup dan malas. Kehadiran Joko Widodo mampu membalik ungkapan tersebut menjadi: "Jika bisa dipermudah mengapa harus dipersulit? Dengan ungkapan tersebut Jokowi membangun sistem perijinan yang efektif, efisien dan transparan melalui One Stop Service atau pelayanan satu atap sehingga memudahkan masyarakat dan investor. Ide dasar Jokowi sangat sederhana, jika ijinnya mudah maka pintu-pintu pungli bisa

27 http://www.liputan6.com/tag/blusukan-jokowi (diakses 11 Oktober 2014). 


\section{R duknal HTSVINDING}

Media Pembinaan Hukum Nasional

ditutup. Sehingga budaya korup dan malas bisa dihilangkan.

\section{Penutup}

Sebagaimana telah dikemukakan dalam pembahasan diatas, diketahui bahwa masyarakat sudah tidak percaya lagi terhadap institusi publik terlebih kepada penyelenggara negara. Institusi publik, terutama yang bergerak di bidang pelayanan publik sudah mendapat stigma negatif dari masyarakat. Anggapan bahwa rumit, lama dan membutuhkan biaya yang banyak sudah melekat pada pelayanan publik oleh pemerintah. Pelanggaran yang dilakukan tidak hanya merugikan masyarakat namun sudah merugikan negara, baik dari sisi keuangan negara yang dapat dikategorikan sebagai tindak pidana korupsi hingga turunnya citra atau wibawa sebagai negara yang baik.

Saat ini pun masyarakat tidak lagi tertarik dengan berbagai program pemberantasan korupsi yang banyak digaungkan oleh pemerintah. Pemerintah dinilai telah gagal dalam menyelesaikan program pemberantasan korupsi terutama dalam bidang pelayanan publik. Reformasi birokrasi yang telah menjadi program andalan untuk menghadirkan birokrat - birokrat yang handal di nilai masih belum berhasil. Terbukti dengan masih banyak nya tindak pidana korupsi terutama di bidang pelayanan publik.

Pemerintahan era baru yang di komandani oleh Presiden terpilih Joko Widodo, secara tegas dan konkret sudah menyatakan perang terhadap pelayanan publik yang sudah bercitra buruk tersebut. Untuk mewujudnyatakan keinginan tersebut tentunya tidak mudah namun harus berani dimulai saat ini dengan melakukan reformasi birokrasi yang memasukkan metode
Volume 3 Nomor 3, Desember 2014

revolusi mental ke dalam program dan kebijakannya.

Kebijakan, program dan kegiatan pemerintahan pada era kepemimpinan mendatang diarahkan dan diposisikan benar sebagai strategi pelaksanaan reformasi birokrasi dalam pemberantasan korupsi untuk menciptakan sistem pelayanan publik yang baik. Reformasi birokrasi benar-benar menjadi ideologi yang terinternalisasi atau tertransformasikan dengan baik dalam bentuk kebijakan atau program pemerintah. Tidak hanya menjadi wacana yang ramai namun tidak ada langkah nyatanya. Dorongan untuk mengatur sistem lelang jabatan, kecepatan dalam sistem pelayanan publik serta pelayanan publik secara elektronik dapat dijadikan momentum awal untuk menginternalisasi revolusi mental ke dalam sistem reformasi birokrasi dan pelayanan publik.

\section{Daftar Pustaka}

\section{Buku}

Atmosudirdjo, Prajudi, Hukum Administrasi Negara, (Jakarta : Ghalia Indonesia, 1990)

Hoesen Koesoemahatmadja,Djenal, Pokok-Pokok Hukum Tata Usaha Negara Jilid I, (Bandung, Alumni, 1979)

Hadjon, Philipus, Pengantar Hukum Administrasi Indonesia, (Gadjah Mada University Press, tahun 2001)

Komaruddin, Manajemen Pengawasan Kualitas Terpadu, Suatu Pengantar, (Jakarta: CV Rajawali, 1986)

Lubis, M. Solly Lubis, Hukum Tata Negara, (Bandung : CV Mandar Maju, 1992)

Lotulung,P.Effendie, Beberapa Sistem tentang Kontrol Segi Hukum Terhadap Pemerintah, (Jakarta :Bhuana Ilmu Populer, 1986)

Osborrne, David dan Ted Geabler, Mewirausahakan Borokrasi, (Jakarta : PT Pustaka Binaman Pressindo, 1990) 
Purbopranoto,Kuntjoro, Beberapa Catatan Hukum Tata Pemerintahan dan Peradilan Administrasi Negara,( Bandung, Alumni, 1985)

Raharjo, Stjipto, Sosiologi Hukum, Perkembangan Metode dan Pilihan Masalah, (Surakarta,Cet. Pertama, UMS Perss, 2002)

Rober Klitgaard, Membasmi Korupsi, penerjemah Hermojo,(Jakarta, edisi ke 3, cetakan ke 3, Yayasan Obor Indonesia, 2005)

Siagian, Sondang P., Patologi birokrasi: analisis, identifikasi dan terapinya,(Indonesia, Ghalia, 1994 )

Utrecht, Pengantar Hukum Administrasi Negara, (Bandung: Ichtiar, cet. 4,1960 )

\section{Makalah/ Artikel/Prosiding/Hasil penelitian}

Hoessein, Benyamin, "Birokrasi dan Pembangunan," makalah disampaikan pada Penyegaran Staf Pengajar bagian Hukum AdministrasiNegara FHUI, Depok, 1982

Irianto,Sulistyowati, "Meretas Jalan Keadilan Bagi kaum Terpinggirkan dan Perempuan Suatu Tinjauan Socio-Legal," Pidato Pengukuhan Guru Besar Tetap dalam IImu Antropologi Hukum pada Fakultas Hukum Universitas Indonesia, 22 April 2009

Langseth, Peter et. Al, The Role of a National Integraty System in Fighting Corruption, The
Economoc Developmen Institute of the World bank, 1997

Pringgodigdo, Ginrindro, "Hukum dan pembangunan," makalah disampaikan pada Program pendidikan Non Degree / bersertifikat bagi Pemuka Madyarakat sebagai realisasi kerjasama Pusat Pengabdian Masyarakat UI dan Pemerintah Daerah Tingkat II Kabupaten Sukabumi, 28 Oktober 1982

\section{Internet}

kpu.go.id/koleksigambar/VISI_MISI_Jokowi-JK http://acch.kpk.go.id/statistik

http://politik.kompasiana.com/2014/07/07/ revolusi-mental-bukan-marxisme-komunisme http://www.liputan6.com/tag/blusukan-jokowi

\section{Peraturan}

Undang-Undang Nomor 28 Tahun 1999, LN Nomor 75 TLN Nomor 3854 Tahun 2009

Undang-Undang Nomor 37 Tahun 2008, LN Nomor 139 Tahun 2008, TLN Nomor 4899

Undang-Undang Nomor 37 Tahun 2008 tentang Ombudsman Republik Indonesia, LN Nomor 139 TLN Nomor 4899 Tahun 2008

Undang-Undang Nomor 25 Tahun 2009 tentang Pelayanan Publik, LN Nomor: 112, TLN : 5038 Tahun 2009 